\title{
Reflections of Egyptian Society in the Campus Fiction: A Study of Radwa Ashour's Specters
}

\author{
Ashraf Ibrahim $\operatorname{Zidan}^{1 \& 2}$ \\ ${ }^{1}$ Faculty of Arts, Port Said University, Egypt \\ ${ }^{2}$ Faculty of Science and Humanity Studies in Al Aflaj, Salman Bin Abdul Aziz University, Kingdom of Saudi \\ Arabia \\ Correspondence: Ashraf Ibrahim Zidan, Department of English, College of Science and Humanity Studies in Al \\ Aflaj, Salman Bin Abdul Aziz University, P.O. Box 710, Al Aflaj 11912, Kingdom of Saudi Arabia. Tel: \\ 966-55-243-1794. E-mail: drashrafibrahimzidan@hotmail.com or drashrafibrahimzidan@gmail.com
}

Received: November 23, 2014 Accepted: January 7, 2015 Online Published: February 25, 2015

doi:10.5539/ells.v5n1p70 URL: http://dx.doi.org/10.5539/ells.v5n1p70

\begin{abstract}
Radwa Ashour is well-known for her satirical attitudes towards political, social issues and her profession. This article studies Specters as an Egyptian campus novel. Campus novels are set at (provincial) universities; they are written to ridicule both the institution/authority and the naivety/false superiority of some academics. This genre can focus on four groups: students, teaching staff, deans, and faculties. Modern campus novels are also involved in discussing other issues outside the borders of universities. This study not only portrays the pitfalls of some professors, but highlights the social and political problems that modern societies encounter as well. This article concludes that readers are shocked and disillusioned because they have regarded that academic life as an example of chastity, purity and wisdom. It also stresses that both the state and the teaching staffs are to blame for that corruption and frailty.
\end{abstract}

Keywords: Radwa Ashour, campus fiction, professors, university, corruption, Specters

\section{Introduction}

Unlike many other women writers, Arab women writers draw on a rich, ancient heritage, which stretches back to [a] civilization that flourished in the region before the Islamic conquest. As for the Arabic heritage, it takes us back to a venerable ancestor, Al-Khans', whose poems and recorded exploits [brave acts] give her a secure position in the canon. Among the anecdotes related about her is this enlightening story: it is said that Al-Khans' went to Al-Nabigha while he was sitting in 'Ukaz and recited her famous Ra'iya poem to him. Al-Nabigha told her, "if Abu Basir (Al-Asha') hadn't already recited to me, I would have said that you are the greatest poet of the Arabs. Go [,] you are the greatest poet among those with breasts." Al-Khans' replied, "I'm the greatest poet among those with testicles, too." (Ashour et al., 2008, p. 1)

Evidently, the encounter between Al-Nabigha and Al-Khans' referred to above testifies to the marginalization of women in literary circles. Samia Mehrez (2005) stresses the fact that the work of women writers highlights women's situations within conventional/hierarchical societies:

Their narratives give voice to the exploited, oppressed, marginalized, and silenced subject. In doing so, they don't always place women at the center of their narratives; sometimes they select situations of their oppressed groups which evoke parallels with the positions of women within our traditional societies. Thus they locate their women characters' problems within the more general and pressing context of dependency and closure in the Arab world at large. (p. 11)

\section{Rational behind the Choice of the Topic}

I have chosen this topic, "Reflections of Egyptian Society in the Campus Fiction: A Study of Radwa Ashour's Specters", for different reasons. First, Radwa Ashour (1946- ) (Note 1) is known for her satirical attitudes towards political and social issues. She is classified as a revolutionary writer. Second, Specters (1999) leans heavily on the experience of an Egyptian campus life. It portrays middle-class characters, manners, and conflicts in contemporary intellectual life. It turns its incisive critical skills to the author's own profession. Third, Ashour uses both traditional and modern styles for treating and presenting her characters and themes even with some sort 
of cruelty. She uses precise and seemingly plain-spoken narrative voices with both direct and indirect free writing styles. Fourth, Ashour admires transparency not as a simplistic tendency to ignore form, but as a technique of merging form and content skillfully. Therefore, the ordinary reader can easily get the message. Sixth, the novel gives due respect to history and autobiography. Finally, this novel mixes satire, black humor, vivid reality, comedy, fantasy, and compassion.

\section{Campus Fiction}

According to David Lodge (2008), Campus fiction is defined as a term used to designate a work of fiction whose action takes place mainly in a college or university, and which is mainly concerned with the lives of university professors and junior teachers - faculty as they are collectively known in America, and 'dons' or 'academics staff' in England. Showalter (2005) argues that "The best academic novels comment on contemporary issues, satirize professorial stereotypes and educational trends, and convey the pain of intellectuals called upon to measure themselves against each other and against their internalized expectations of brilliance" (p. 4). This genre has come into light in the middle of the $20^{\text {th }}$ century. However, Charney (2005) suggests that even Plato's Dialogues can be classified as "college novels" since they discuss academic freedom:

It has also been acclaimed that there are "two kinds of students" in Chaucer's Canterbury Tales (c. 1387). In the $12^{\text {th }}$ - century lovers Heloise and Peter Abelard have been cited as a classic example of the romantic and sexual affair between a male professor and a female student. However, these works do not reflect any sense of an academic milieu. (p. 10)

Campus fiction is usually comic or satirical. The action is not always set within the enclosed realm of a university. It satirizes such an academic life. It has achieved a remarkable success. It seems to echo a note of protest or resentment against the values of the middle class. It has examined a lot of critical issues using both attractive narrative styles and meticulous insights into common problems. It shows a bitter mocking state of being as man is devalued and culture is in crisis. Chris Baldick (1990) in The Concise Oxford Dictionary of Literary Terms gives this definition:

Campus novel is a novel, usually comic or satirical, in which the action is set within enclosed world of university (or similar set of learning) and highlights the follies of academic life. Many novels have presented nostalgic evocations of college days, but the campus novel in the usual modern sense dated from the 1950's: Mary McCarthy's The Groves of Academe (1952) and Kingsley Amis's Lucky Jim (1952) began significant tradition in modern fiction including John Barth's Giles Goat-Boy (1966), David Lodge's Changing Places (1975) and Robert Davis's The Rebel Angels (1982). (p. 30)

The plots and characters are thoroughly distinguished because of the following reasons:

The plots of campus novels may be totally different and have various functions. Sometimes the plot of campus novel is woven around the criticism of the real world outside the university walls as the case in the novel called Dog. It may also deal with the struggle between the values of the academy and values of industry and business and its usefulness for the society in general as the case in Nice. Or the plot may dwell upon the description of sexual harassment as the case in Der Campus. (Felsberg, 2008, p. 12)

This arguably academic novel gives us a comprehensive view of different themes through the eyes of professors, staff, assistant lecturers, administrators and students. It sheds more light on the lives of academics fleeting from one place to another for literary fame and other ends, especially striving for money/women: "I have a contract with Euphoric State that says nobody in the humanities is to be paid more than me" (Nice Work, p. 329). Martin Hilsky (1993) argues that professors have the character trait of smallness; they are all very emulative, envious and their only aim is a quest for reputation and the knowledge of the latest literary criticism (p. 117). It gives readers the opportunity to share and take part in the narrators' viewpoints. These novels also give panoramic epitomes of miscellaneous clashes for administrative offices, personal disputes and unprecedented plagiarism. Moreover, they highlight the political, social, and economic problems which academics, in particular, have thoroughly come across. However, they have gone beyond the boundaries of the campus by discussing and examining the treatises and issues which society, in general, embodies, the university being a microcosm of that society.

The main characteristics of campus fiction include the use of innocent and naive protagonists, distinctive plots, sarcastic tones, and a number of stylized secondary characters. The style usually takes on the form of popular satire. It raises itself to a level of seriousness. It only shows the weak sides of a society in order to arouse critical laughter. These novels have pinpointed the states of anger which people have to abide by. They are also more concerned with casting a cold eye on the harsh world of academics: 
The simple paradigm of the campus text (arguably deriving from Kingsley Amis's Lucky Jim (1954) has, therefore, four common conventions, centered on the academic's struggle for survival in an often surreal scholarly world, and strong questioning of whether such survival is worth the cost. Thus, (1) the (usually male) academic protagonist is satirized, and secondary academic figures caricatured, in order to indicate his naiveté, (2) his department/university is shown to be a place of politicking, an environment that requires considerable cunningness if it is to be survived, and (3) the tale hinges on the academic's decision whether to opt for the life of the mind or the life of desires, whether sexual, status-oriented, or commercial lust, and this moral dilemma is often developed in the context of a fight to gain tenure, status, or to keep his position. In certain variations the moral dilemma expands to include a relationship or family issue, which again reveals the academic's inability to deal with practical dilemmas. Finally, (4) the academic either wins the battle to stay in academe, or escapes, and here conventionality ends as the protagonist rediscovers a creative originality once freed from generic confines. (Brown, 2008, p. 592)

According to Shridevi (2011), there are two reasons behind the emergence and development of that genre:

The first is the sociological reason - that in the period after the Second World War there was a great expansion in university education. Many new universities were built and the old ones expanded. There were job opportunities in arts faculties which attracted aspiring and practising writers. In America where 'Creative Writing' was already there in the academic syllabus, professional writers were hired to teach it along with conventional literature courses. So university teaching with its generally agreeable conditions and a source of steady income became a welcome choice to the writers. As authors derive ideas and subject matters from the milieu of their habitat, it is obvious that both countries produced a steady stream of campus novels. It is interesting to note that most of these novels are concerned with teachers in the Arts or Humanities fraternity, because that is where most university-based novelists work. Another reason is that the novelist before writing his novel should create or imagine a world which has some kind of logical relation to the real world, within which he can explore the themes that interest him through the narrative. The university or college provides such a world ready-made - a small world which is a kind of microcosm of the larger world. (p. 3)

The English society was reshaped because of the World War II. The government had to pass some social-reform laws, such as 'The Education Act' (1944). This law enabled a lot of the lower classes people to join universities and get jobs: David Lodge, Malcolm Bradbury and Kingsley Amis are good examples. According to Irena Žampachová (2006), the upper class did not favour this social change, but as the government became involved in the social and economic field more than ever before, the process of levelling society was natural and inevitable (p. 7).

\section{Specters as a Campus Novel}

Distinguished novels not only unveil depths of reality, but they predict the future as well. Naguib Mahfouz's novels foreshadowed the 1967 Arab defeat at the hands of Israel. Specters predicted the downfall of some of the Egyptian universities in addition to the shameful misdeeds committed by some of their chancellors and staff members. We could be acquainted with that frightening picture through the documented semi-autobiographical narrative of the novelist and that of the fictional character Shagar (Qareen/Ka/double). Ashour (2000) says:

I would like to add a few words about my last novel: Atiaf: Specters. It's a semi-autobiographical narrative, a partial record of my life intertwined with that of another character of my age and profession, a kind of double if you want, or Qareen or Ka (The creative energy which accompanies a person from the moment of his/her birth to the afterlife in ancient Egyptian myth). (p. 91)

Shagar studied History at Cairo University: it is the same faculty at which the novelist studied English from 1963 to 1967. Mona Michael (2004) thinks:

Women have feminized the Avant-garde. Radwa Ashour (in Arabic) and Ahdaf Souweif (in English) have written powerful memoirs and short stories exploring yet another aspect of the modern westernized Middle Eastern women. They are openly daring in their treatment of the taboo subjects of sex and homosexuality. (p. 138)

Shagar is summoned and affronted by the dean because she has taken part in the 1971 students' strike: her duty, as an assistant lecturer of modern History, is to be in the core of that uprising in order to record its outcries and follow up its development. She is chronicling the massacre of Deir Yaseen (11-4-1948). In a review of Radwa Ashour's Specters in Banipal, Mona Zaki (2011) says: 
The narrative closest to Shagar's heart is the massacre of Deir Yassin. Presented as a research paper at a conference, the inhabitants are some of the specters in this book. They are "called up", named and described amid the terror and confusion as testimony against the Zionist project. Shagar's paper gets a cold reception at the European conference. Sabra and Shatila are also described-again specters to horrific crimes against unarmed civilians. Ashour/Shagar pertinently asks whether it is in the power of any historian to follow the threads that make up the fabric of his life. The end of the book lets us know that narrative is personal pain. Evoking the ancient Egyptian image of the woman/cow goddess forming a roof over the horizon with arms and legs as pillars, Ashour asks if the mouth would open to release words "brighter than beams of light, swifter than hunting dogs, lighter than shadows.

Shagar gives the novelist a sense of freedom to record different stories about her personal, familial, creative, and academic history. The novelist also highly dissects the social and political issues of the Arab region. The Egyptian universities used to be pioneers of national political awareness; they have generated a lot of student martyrs on campus. Muhammad Ezzat Al Bayumi is the first martyr of 1919 Revolution. In 1991, Khaled El Waqqad was killed for demonstrating against invading Iraq. On $25^{\text {th }}$ January 2011 , the Egyptians, led by university graduates, have defeated fear and shame. Unfortunately, some universities have recently been led by some professors who were appointed by security and therefore loyal to authority. The dean insults Shagar because she is patriotic:

"How can we entrust you with the teaching of our students?" He went on: "You know that we can cancel the appointment of a teaching assistant at any time. The assistant is not a member of the faculty, he is a student researcher, nothing but a student researcher, a temporary employee, on probation." ...He raised his voice angrily: "You haven't gotten your doctorate yet, and you aren't a member of the faculty. I can dismiss you from the university!" (Specters, 1999, p. 86)

He is expecting apology, but gets nothing: "Did you apologize?" her grandfather, Abdel Ghafar asked her. "No, I didn't" (Specters, p. 86). Later, she has to resign after her colleague's sudden death (Yusuf). Deans in the past were like medieval knights; their academic careers may be valued as a kind of spiritual purification and self-improvement. In Specters, modern scholars remind us of what P. R China (2010) says about scholars in David Lodge's fiction who: "mostly aim at the seizure of power, glory, fame and physical enjoyment without much consideration of the holiness of the academic study itself" (p. 137).

The result, therefore, may be pleasing or depressing. Shagar parodies the Egyptian ways of life. She also gives modern campus fiction new and enduring figures to laugh and laugh at. The Egyptian protagonist is serious and hard-working; he does his best to reform his society, but in vain. He is doomed to suffer. In short, he is a mythological/typical character. Unlike the protagonist of Lucky Jim, Ashour's major characters never withdraw from politics: Shagar may be killed because of defending the Palestinian cause. In 1981, the novelist was a detainee.

Focusing on the Egyptian University, Specters tackles administrative corruption, continual enmity among some academics, publishing ban, plagiarism, promotion systems, supervising dissertations, syllabus distribution, sexual relations, cheating in exams, arrogance, academia pretentiousness, random decisions of department heads, exile, assassinations, love, romance and imprisonment. The main characters are interested in history. Specetrs depends upon memoirs, diaries, imagination, and facts. It sheds more light on cultural crises because of oppression, torture, and imprisonment. It does not ignore such social issues as hypocrisy and some other social disease in colleges:

The proctors stand by the doors, 'keeping watch,' so that they can warn the students if one of the professors is approaching. Another girl: "The proctors help the students cheat - one of them might be asked to take a 'crib sheet' from a student to one of her classmates in a different test section." Now a boy: "People are weak by nature, and when we find that others whose level is below ours and who don't try as hard are getting higher grades, and that cheating is the norm, then we cheat." (Specters, 1999, p. 146)

Cheating has become the dominating and powerful institution. Shagar is quoting Hamlet's saying: "Something is rotten in the state of Denmark!" My God, was she, at the age of 50, to be compelled to live the experience of the adolescent Hamlet?" (Specters, p. 149). Kingsley Amis (1954) maintains that

They [students] do not go to universities to acquire culture, but to get a job, and when they have got one, scamp it. They have no manners, and are woefully unable to deal with a social predicament. ... Their idea of a celebration is to go to a public house and drink six beers. They are mean, malicious and envious. They will write anonymous letters to harass a fellow undergraduate and listen to a telephone conversation that is 
no business of theirs. Charity, kindness and generosity are qualities that they hold in contempt. They are scum. They will in due leave the university. (Lucky Jim, 1954, p. 21)

Ashour presents a cast of characters who struggle with the discovery that they are not free, but they are handcuffed and fettered by themselves, society, and some other forces. Their revolt is disregarded, leading them to lose confidence in everything because of the political regimentation. Shagar is a fictional character. She does not narrate the autobiography of Radwa. Radwa and Shagar, however, complement each other in order to portray their composite experiences from different angles. Both of them dream of freedom in the full sense of the word. They have suffered a lot and are doomed to undergo more sufferings. They do not want merely to be safe and self-satisfied academic bureaucrats like Jim Dixon in Lucky Jim (1954) who is as proud of his beer tastes as he is irritated by his beer income. To hold on to his teaching post he becomes involved in a series of tawdry, inept and sometimes hilarious maneuvers. This display of self-serving clownmanship has captured his saga through 18 printings and left countless Britons alternately fuming and guffawing. (Dirda, 1957)

Some of the Egyptian universities have taken biased attitudes against those bearded and veiled students (those who have Islamic attitudes). They have been ignoring the objective criteria of evaluation. Most of them (those eminent students) are deprived of their legal rights of appointments though they are intelligent, exceptionally talented, helpful and attentive. They have to either change their behavior or to have their eyes on their colleagues and students. This highlights grief and ingratitude. Khalil is one of those students: he has the right to be a language instructor. It would be difficult for him to get that honorable job as long as he is bearded and in jallabyia. He has to change his own behavior in order to be accepted. His department board thinks of sending him abroad to do post studies:

Did you See khalil? I talked to him about the jilbab, and I made it clear to him that it would be impossible for the university to give him an appointment [job] if he let his beard grow and wore a jilbab and a skullcap. I talked to him at length, and - thank God - our lord gave him guidance, and he listened to my advice. She was smiling now, proud of her accomplishment. "I saw him today at the college, and he was wearing a shirt and trousers. He kept the beard - that's it." (Specters, 1999, pp. 250-251)

Khalil thinks that Dr Shagar, his professor, has chosen to be beautiful and to be defeated "I didn't want to be defeated or persecuted" (Specters, 1999, p. 253). Khalil refuses to be like Gamal Hamdan (1928-1993) who lived in isolation and died at an earlier age depressed and alone. He has to respond to pressures:

You're oversimplifying, professor. A person chooses sometimes to work to change reality-this seems feasible to him. He bears the burdens of his choice, and there's no problem with that. I discovered that I don't have it in me to change the way things are, and I don't see that I have any power I might bring to bear for the sake of such change. In short, I found that the question was whether one was to be the wolf or the lamb. Better to eat than be eaten, I said. (Specters, 1999, p. 253)

This may indicate the end of intellectual era. We wonder if history is a perpetual improvement. The new academics are rather poor. Most of them withdraw from political and social life. This situation reminds us of Morris Zapp in David Lodge's Small World (1984): He is struggling to keep pace with the fashion: he has to change his academic interests. He also leaves Jane Austen's fiction. Finally, he becomes interested in up-to-date theories (e.g. poststucturalism).

Dr Yusuf, a lecturer in History department, is an innocent liberal hero. He attempts to find a way through such a strange and sometimes threatening world. He has a moral and philosophical attitude. The satirical element is more biting, the atmosphere is more menacing, and the conclusion is more disheartening. Alienation and nihilism dominate the novel. Yusuf is hard-working and loyal to his institution. He wastes neither his time nor his students' contrary to the hero of David Lodge's Lucky Jim.

Ashour also stresses the value of scholarly researches in addition to the integrity of some professors. Consequently, she rails at those professors who seek to supervise a lot of PhDs, especially in provincial universities, in order to achieve some ends other than engaging in academic concerns. They rarely read or value their students' efforts; therefore, it is sometimes difficult to get a well-qualified paper - this scarcely occurs in departments of English. Some universities have been degraded and distorted. Some of their staff members have plagiarized complete papers in order to get promotion or take part in international conferences. Shagar and Yusuf revolt against those faked values and codes at first inwardly and at last outwardly. Their rebellion, however, is marginalized and silenced. This situation is dramatically and perceptively portrayed throughout the novel. They discuss those matters with the dean, but in vain: "It is not a point of view,"Dr Yusuf shouted. "We are destroying the university with our hands! He rose to his feet, and roared, "You are destroying it!" (Specters, 1999, p. 257). This also reminds us of Henry Devereaux in Russo's Straight Man (1998) who is advised to nominate four of his 
colleagues for firing in order to be a dean. He refuses and resigns restoring his psychological and physical health in addition to his wife's approval.

Dr Yusuf parodies savagely the dean's substitution of trends of morals and commitments: the dean is responsible for razing and devastating the academic system. He is not extremely malicious, but he is a bad driver because he is not aware of the dangers of such academic matters. Yusuf does not bear both the negative reaction of the dean regarding these plagiarisms and his involvement in the destruction and distortion of that great university. $\mathrm{He}$ takes satire to higher limits to highlight his grief. He is aware of those social problems such as rootlessness, infidelity, abuse, and other evils. Consequently, he dies of absent-mindedness and arrogance. He could not get emancipated from the confusion of some Egyptian academic lives. His college alone takes responsibility for his death. Some other academics have been denied supervision, offices, and sometimes fired out:

A professor plagiarized a book belonging to a departed colleague and published it in his own name. The victim's children didn't write to the newspapers - they went to the court. The court's decision came down, confirming the theft. . . . He [the accused professor] came, smiling radiantly, as happy as he could, receiving congratulations, because the university had appointed him head of the department in which he [Dr Yusuf] taught. (Specters, p. 258) ... She [Dr Shagar] stood up. She got as far as the door, then turned and stared at him [the dean]. "I don't like to think who will come after Yusuf. I see the coffin and the pallbearers, and I know it's the university that's in the coffin. (Specters, 1999, p. 260) (Note 2)

This nightmare can be seen day and night. It has become the destiny of most academics. This dramatizes the tension arising out of the clashes between conscience and materialism. They are politically, academically, socially, and economically humiliated. This false claim of the superiority of that academic life is thoroughly domineering in the full sense of the word. This increases the reader's critical and literary competence. It also shows that there is no means of communication between those academics and the Cabinet. Chaos and Machiavellianism have outweighed everything. Thus, in specters the dominant patterns of contemporary society are pensively welcomed at the expense of the values of the older, more local traditions. Qualified academics could not tolerate such fatal atmosphere, so they have to immigrate, resign, and commit suicide or to be detained. Some professors' loyalty, nowadays, is to their own life and their top brass, not to their educational institutions or their students.

Janice Rossen (1993) states that the university can be a place of exclusion and marginalization, rife with class-consciousness, misogyny, competition, and xenophobia (p. 7). Some academics may be dismissed because of their philosophical and religious ideas. Muhammad Ahmad Khalafallah (1904-1983) presented a PhD entitled The Art of Narration in the Holy Qur'an in 1947. He was accused of atheism. He had to give up his paper in order to restore his legal academic career. This denotes that fighting innovation and creativity is a must in most of the Arab world. Taha Hussein (1889-1973) should be added to the top of the list. He was about to lose his job because of his famous book Pre-Islamic Poetry (1926). He, however, was supported by Saad Zaglul's Cabinet: it was a Coalition/ Liberal government. Sheikh Ali Abdelrazeq's (1988-1966) certificate had to be wiped out and obliterated due to his book Islam and the Foundation of Governance (1925). He was unlucky: the minority of the Cabinet by Ziwar Pasha (1864- 1945) took a fanatic reaction against his book. However, not all academics are punished as badly as John Harding's English professor, Michael, Cole, in Where the Sun Shines (2002), who not only loses his job after a sex scandal, but suffers a stroke that condemns him to life as a helpless, silent invalid, endlessly being read the poems of Donne by his wife. (Brown, 2008, p. 599)

Specters is distinguished by its moral sense, narrative strength, and elegant mixture of reality and fantasy. The novelist uses a variety of procedures - including black comedy, satire, history, and allegory —in order to depict that academic life. This novel is primarily concerned with the revival of the human spirit in characters. Those characters quest for their rightful place in the world and do not seek to hurt others.

The language of dialogue among some academics denotes disrespectability, arrogance, brutality, materialism, triviality, ignorance, and psychological diseases. Those people, unfortunately, are ready to deceive, cheat, murder, rape in order to fulfill their selfish ends. It is difficult nowadays to enjoy such an academic life. Neither some academics nor governments have real intentions to reform or develop that rather rotten system of education. That political regime is fully satisfied with that stupendous corruption. Ashour uses contemporary characters, not modern ones. She believes in the ability of ordinary prose to represent life. She is more concerned with what people do. She is not subjective, elusive, multiple, or baffling. This encourages her to return to models, which modernists have rejected. She succeeds in exploiting the linguistic potentialities of the language and at times moved us into poetic space. She revisits history from philosophical perspectives. She could bring historic truth in a vibrant reality. She creates vivid personas in her novel. In lucid language, she explores the psychological 
impact of everyday life, emphasizing the passage of time on the ordinary people, while foregrounding the intellectual's estrangement in Egypt.

Although Specters is set on a college campus, we rarely see students. The novelist attempts to alert us that her campus novel does not examine the follies and absurdities of students. Instead, it rapidly becomes apparent that it ridicules the coarse language and immature behavior of some academics and the faculty. The novel is narrated in the first-person. It is not chronologically developed: there are enough leaps back and forth in time. The characters are sharply and clearly drawn. Finally, the novel abounds in verbal wit, comic gesture, and piercing satires.

As far as the end of the novel is concerned, Qualey (2011), in a review of Specters, says,

Radwa's alter ego is allowed to vent the full weight of her life's disappointments and frustration. Shagar screams at students, complains to the dean, resigns her university position, severs her phone cord with scissors, and drives away from Cairo. These are things, one imagines, the "real" Radwa Ashour daydreams of doing. (p. 32)

In brief, Specters shows that politics is dominating and distorting everything in order to persist. In other words, politicians are ready to crush down and wipe out everything and everyone in order to perpetuate their status. Most academics are unable to make use of their scientific researches to develop and enrich their countries. Therefore, their countries are doomed to live in ignorance and illness in order to be easily ruled and chopped. Finally, I quote George Orwell's saying (1946): "The political language — and with variations this is true of all political parties, from Conservatives to Anarchists - is designed to make lies sound truthful and murder respectable, and to give an appearance of solidity to pure wind."

\section{Conclusion}

Specters is a short survey of the Egyptian academic life. Readers have regarded that life as an example of chastity, purity, and wisdom. However, we are shocked, deceived, and disillusioned. This novel demonstrates the cries of those (Shagar/Yusuf) who are severely wounded in order to change and reform their countries. Therefore, they are clearly different from the Angry Young Men figures/heroes. The latter have revolted against classifying societies into classes and beliefs. However, they have no clear philosophy concerning changing and developing their societies. They are ready to ruin, not to build; they are also unable to give good political analyses; they only think of themselves without realizing that they themselves have turned into predators. In Look Back in Anger (1957), for example, Jimmy, as well as Osborne, is not interested in the public life of his country: they are not involved in any political/social activities.

\section{Acknowledgement}

This project was supported by the Deanship of Scientific Research at Salman bin Abdul Aziz University under the research project 2014/02/1594.

\section{References}

Amis, K. (1954). Lucky Jim. Intr. by David Lodge. London: Penguin.

Ashour, R. (1999). Specters. Trans. Barbara Romaine (2010). Cairo: The American University Press.

Ashour, R. (2000). Eyewitness, Scribe and Storyteller: My Experience as a Novelist. The Massachusetts Review, $41(1), 85-92$.

Ashour, R., Ghazoul, F. J., \& Reda-Mekdashi, H. (Eds.) (2008). Arab women writers: a critical reference guide 1873-1999. Trans. Mandy McClure. The American University: Cairo. http://dx.doi.org/10.5743/cairo/9789774161469.001.0001

Baldick, C. (1990). The Concise Oxford Dictionary of Literary Terms. Oxford: Oxford UP.

Brown, S. D. (2008). Is There Life Outside of (the Genre of) the Campus Novel? The Academic Struggles to Find a Place in Today's World. The Journal of Popular Culture, 41(4), 591-600. http://dx.doi.org/10.1111/j.1540-5931.2008.00538.x

Charney, M. (2005). Comedy: A Geographic and Historic Guide. Santa Barbara: Greenwood publishing group, Incorporated.

China, P. R (2010). Postmodernism or Neo-Realism: On Parody in David Lodge's Campus Novel Small World. Canadian Social Science, 6(3), 133-142. 
Felsberg, M. (2008). The Campus Novel: An Intellectual Comparison. Retrieved from http://shodhganga.inflibnet.ac.in/bitstream/10603/8396/5/05_chapter\%201.pdf

Hilsky, M. (1992). Academic British Novel. Jinocany: H\&H ve spolupráci s FF UK.

Lodge, D. (2008). Nabokov and the Campus Novel. Cycnos, 24(1). Retrieved from $\mathrm{http} / / /$ revel.unice.fr/cycnos/document.html?id=1081

Mehrez, S. (2005). Egyptian Writers between History and Fiction: Essays on Naguib Mahfouz, Sonallah Ibrahim, and Gamal al-Ghitani. The American university Press: Cairo.

Michael, A. M. (2004). Seen and heard: a century of Arab women in literature and culture. Northampton: Oliver Branch Press.

Orwell, G. (1946). Politics and the English Language. Retrieved from https://www.mtholyoke.edu/acad/intrel/orwell46.htm

Osborne, J. (1957). Look Back in Anger. New York: Criterion Books.

Shridevi, P. G. (2011). The Origin and Development of Campus Novels in Indian English Literature. Irwle, 7(2), $1-9$.

Qualey, M. L. (2011). A Twinned Narrative. Women's Review of Books, 28(2), 30-33. Retrieved from $\mathrm{http}: / /$ arabit.wordpress.com/

Rossen, J. (1993). The University in Modern Fiction. When Power is Academic. New York: St. Martin's Press.

Russo, R. (1998). Straight Man. London: Vintage.

Showalter, E. (2005). Faculty Towers: The Academic Novel and Its Discontents. Philadelphia: U of Pennsylvania $P$.

Zaki, M. (2011). Mona Zaki Reviews. Banipal Magazine of Modern Arab Literature: Celebrating Adonis, 41(2). Retrieved from http://www.banipal.co.uk/book_reviews/76/spectres-by-radwa-ashour/

Žampachová, I. (2006). Reflections of British Society in the Campus Novel (B.A. Thesis). Brno: Masaryk University.

\section{Notes}

Note 1. Radwa Ashour is both a radical and contemplative figure. She has been an important public intellectual and writer of fiction in Egypt. She has been participating in the founding of the Higher National Committee for Writers and Artists in Cairo since 1973. She is a professor of English literature at Ain Shams University. She has published seven novels, two collections of short stories, and five critical books. She is greatly interested in history and language. Her novels denote experience, quest for identity and heritage. Specters combines both fact and fiction. Art should require a kind of empiricism, courage, and adventure.

Note 2. In Lucky Jim, Jim's article is plagiarized by L. S. Catton; he is a shady academic; he never actually appears in the novel; he has got a good position in Argentina as a department chair:

There could be no doubt about it; this article is either a close paraphrase or a translation of Dixon's own original article. At a loss for faces, he drew in his breath to swear, then cackled hysterically instead. So that was how people got chairs, was it? Chairs of that sort, anyway. Oh well, it didn't matter now. But what cunning old $[\ldots]$ That reminded him. One of the things he'd got to do today was to see Johns and abuse, or even assault, him for his latest piece of treasury. He went out and down the stairs. (p. 229)

\section{Copyrights}

Copyright for this article is retained by the author(s), with first publication rights granted to the journal.

This is an open-access article distributed under the terms and conditions of the Creative Commons Attribution license (http://creativecommons.org/licenses/by/3.0/). 